\title{
Attributes and Roles Assigned to Characters in Children's Writing: Sex Differences and Sex-Role Perceptions
}

\author{
Mary L. Trepanier and Jane A. Romatowski \\ The University of Michigan-Dearborn
}

This research examined the creative writing of 180 elementary school children for evidence of sex difference and sex-role perceptions. Stories were analyzed for frequency of male and female characters, attributes, and roles. Writers were equally divided by sex and into three age groups-grades 1-2, 3-4, and 5-6. Results suggest that the total number of characters, roles, and attributes was equivalent. However, the distribution of male and female characters, roles, and attributes differed with male and female writers. Female writers included significantly more female characters and assigned more attributes and roles to these characters. Nevertheless, in the stories of both male and female writers, there was a predominance of male characters and assignment of attributes and roles to male characters. The findings support the development and implementation of a nonsexist curriculum.

The stages in children's development of sex roles and the acquisition of gender identity have been described by Kohlberg. According to Kohlberg's (1966) cognitive developmental theory, children actively construct sex-role attitudes and perceptions by organizing rules from the world around them. This developmental process is dependent on environmental interaction and maturation.

In children's construction of sex-role attitudes and perceptions, a major environmental influence is the school, its curriculum, and its activities. Among these activities, creating writing, as a vehicle for personal expression, is a rich resource for investigating sex differences and sex-role perceptions. Concepts and attitudes regarding the roles and characteristics of males and females in society should be evident in stories written by 
children. Changes in these perceptions and attitudes across various grade levels should also be apparent. However, little research has examined the creative writing of children from this perspective.

The purpose of this study was to examine children's writing for evidence of sex difference and sex-role perceptions. The following questions were addressed: Are there differences in the frequencies with which male and female characters appear in the stories of male and female writers? Are there differences in the frequencies and the types of attributes (physical, personal, ability) assigned to male and female characters by male and female writers? Are there differences in the frequencies and the types of roles assigned to male and female characters by male and female writers?

\section{METHOD}

\section{Subjects}

The subjects of this study were 180 children, 90 boys and 90 girls, enrolled in public and private schools of a large metropolitan area. Subjects were chosen at random from approximately 700 children who attended a university-sponsored "Young Authors' Conference." Children were selected to attend the conference by their teachers or other school personnel. The children in this study reflected a variety of socioeconomic and ethnic backgrounds and 112 area schools.

Subjects were divided into six groups, with 30 children in each group. The groups were: grade 1-2 males, grade 1-2 females (6-8-year-olds); grade 3-4 males, grade 3- 4 females (8-10-years-olds); grade 5- 6 males, grade 5- 6 females (10-12-year-olds).

\section{Procedure}

Within their own classroom settings, students wrote stories in response to open-ended classroom assignments. The responsibility for implementing the classroom creative writing project rested with individual teachers in participating schools. University guidelines instructed teachers to launch programs in creative writing and to encourage all the children to write. They were also instructed not to represent the conference as a "contest" where only "winners" from the class would attend. Children had the freedom to choose topics of their own, to construct their own plots, to include as many or as few characters as they wished, and attribute to their 
characters roles and attributes which would develop the story. In every case, the story was to represent the individual effort of the author. The teacher's role was to assist an individual only in proofreading and editing if that were necessary. The stories were voluntarily donated by the children to the university for teaching and research purposes at the time of the conference.

Four trained research assistants read the 180 books and recorded characters, attributes, and roles. Interrater reliability among research assistants ranged between $84-97 \%$. All books were also read and scored by the two authors.

\section{RESULTS}

\section{Characters}

Stories were examined for the frequency of female and male characters. Characters were only included when people, animals, or imaginary creatures were assigned a gender by the author. The frequencies of male and female characters are reported in Table I.

The total number of characters generated by male and female authors was equivalent. However, writers differed in the gender distribution of their characters. Analysis suggested a significant relationship between the sex of the author, sex of the character, and grade of the author, $\chi^{2}(7, N=$ $180)=70.808, p<.001$. Further analysis suggested that grade was not related, but sex of author and character were significantly related, $\chi^{2}(1, N$ $=180)=67.634, p<.001$. To examine this relationship cell chi squares were converted to standardized residuals and compared.' Male authors included significantly more male characters than did female authors $(r=$ $8.2, p<.001$ for male authors), and female authors included significantly more female characters than did male authors $(r=8.2, p<.001$ for female authors). While both male and female authors included more male characters than female characters, the difference in frequency between male and female characters was less for female authors than male authors. For example, of the 125 characters generated by grade 5-6 male authors, 114 $(91 \%)$ were male characters and $11(9 \%)$ were female characters. Of the 135 characters generated by grade 5-6 female authors, 73 (54\%) were male characters and $62(46 \%)$ were female characters. 
Table I. Number of Male and Female Characters Assigned by Authors at Each Grade Level ${ }^{\alpha}$

\begin{tabular}{lrllllll}
\hline & \multicolumn{2}{c}{$\begin{array}{c}\text { Male } \\
\text { Authors }\end{array}$} & \multicolumn{2}{c}{$\begin{array}{c}\text { Female } \\
\text { characters }\end{array}$} & \multicolumn{2}{c}{ characters } & \multicolumn{2}{c}{ Total } \\
\hline Grades 1-2 & & & & & & \\
Males & 69 & $(82)$ & 15 & $(18)$ & 84 & $(13)$ \\
Females & 49 & $(58)$ & 36 & $(42)$ & 85 & $(14)$ \\
Grades 3-4 & & & & & & \\
$\quad$ Males & 81 & $(84)$ & 16 & $(17)$ & 97 & $(16)$ \\
Females & 58 & $(59)$ & 41 & $(41)$ & 99 & $(16)$ \\
Grades 5-6 & & & & & & \\
$\quad$ Males & 114 & $(91)$ & 11 & $(9)$ & 125 & $(20)$ \\
Females & 73 & $(54)$ & 62 & $(46)$ & 135 & $(22)$ \\
$\quad$ Total & 444 & $(71)$ & 181 & $(29)$ & 625 & \\
\hline
\end{tabular}

"Percentages are given in parentheses.

\section{Attributes}

The stories were also analyzed for the total number of attributes assigned to characters. An attribute was defined as either physical (color, size, age, appearance, or physical condition) or personal/ability (personality trait, ability or lack of ability, or temperament). Only actual words used by the subject, not implied attributes, were included. The frequency of attributes assigned to characters is reported in Table II.

Analysis suggested that the total number of physical and personal/ ability attributes assigned by male and female authors at each grade level was approximately equivalent. However, with increasing age, more attributes were ascribed. Of the 689 total attributes assigned, grade 1-2 children assigned 110 attributes (16\%); grade 3-4 children assigned 205 attributes $(30 \%)$; and grade 5-6 children assigned 374 attributes $(54 \%)$.

Male and female authors ascribed an equivalent number of attributes to all characters, but differed in the number of attributes they assigned to each sex. An omnibus chi square suggested that the sex of author, sex of the character, and author's grade were significantly related, $\chi^{2}(7, N=180)=$ $113.169, p<.001$. An examination of cell chi square suggested that at the grade 1-2 level, both male and female authors ascribed significantly more attributes to their male characters $(r=3.6, p<.001$ for male authors; $r=$ 2.6, $p<.01$ for female authors) than to their female characters ( $r=-3.4, p$ $<.001$ for male authors; $r=-2.9, p<.01$ for female authors). At the grade 3-4 level, a developmental change was emerging. While male authors were still ascribing significantly fewer attributes to female characters, female authors were beginning to ascribe more attributes to their female 


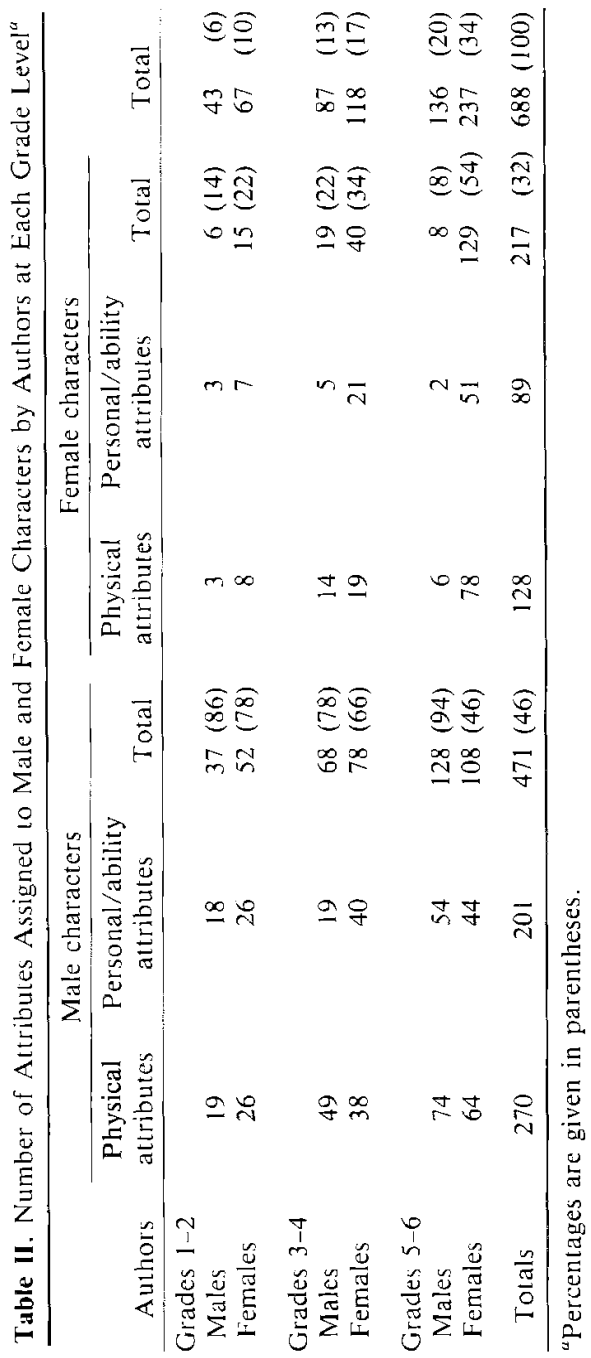


characters. By the grade 5-6 level, for male authors, the discrepancy between the number of attributes ascribed to male characters $(r=9.8, p<$ $.001)$ and the number ascribed to female characters $(r=-12.7, p<.001)$ was most marked. On the other hand, female authors at the grade $5-6$ level assigned significantly more attributes to female characters $(r=19.2, p<$ $.001)$ than to male characters $(r=-16.3, p<.001)$.

When separate analyses for physical attributes and for personal/ ability attributes were conducted, results were similar to those found for the combined total of attributes. The omnibus chi square for physical attributes was $\chi^{2}(7, N=180)=72.5, p<.001$. The omnibus chi square for personal/ ability attributes was $\chi^{2}(7, N=180)=51.4, p<.001$. A comparison of cell chi squares yielded the same pattern of results.

Physical attributes were further examined to determine whether any predominant categories were used by either male or female authors. At each grade level authors tended to ascribe an equivalent number of attributes in each category: physical condition (26\%), size $(24 \%)$, appearance $(21 \%)$, color $(17 \%)$, and character's age $(12 \%)$.

Personal/ability attributes were further classified by type (i.e., positive, negative, or neutral). Examples of positive attributes were courageous, determined, and brave; examples of negative attributes were mean, disagreeable, and forgetful; examples of neutral attributes were new and old. Because of low cell frequencies, an omnibus chi square analysis comparing positive and negative traits was not conducted. However, when collapsing across author, character, and/or grade, interesting trends were noted. Male and female authors together ascribed more positive attributes $(155$, or $66 \%)$ than negative attributes $(78$, or $34 \%)$. These positive attributes were more often ascribed to male characters than female characters $(115$, or $74 \%$ for male characters; 40 , or $26 \%$ for female characters). The majority of positive and negative attributes assigned to female characters was assigned by female writers: Female writers assigned to their female characters 37 positive attributes ( $92 \%$ of total positive) and 23 negative attributes ( $88 \%$ of total negative). Male writers assigned to their female characters 3 positive attributes ( $8 \%$ of total positive) and 3 negative attributes ( $12 \%$ of total negative).

\section{Roles}

The number of roles assigned to male and female characters was compared. Roles were defined as (1) occupational, such as detective, doctor, astronaut, or (2) family, such as mother, father, aunt. Only roles named by the subject and not implied by the story content were included in 
Table III. Number of Roles Assigned to Male and Female Characters by Authors at Each Grade Level ${ }^{\alpha}$

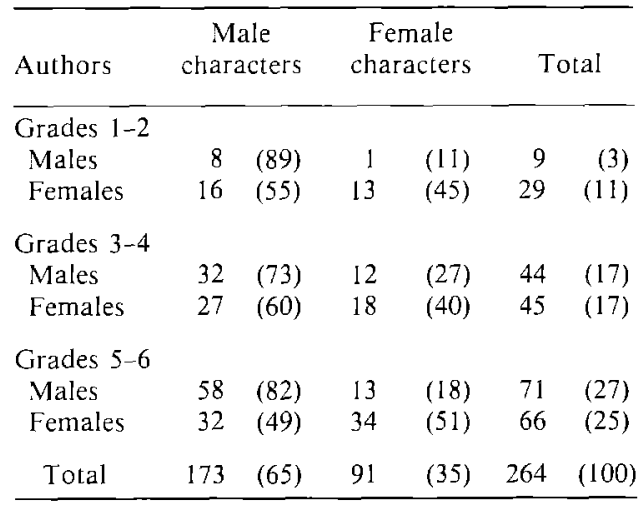

"Percentages are given in parentheses.

the analysis. The frequencies of occupational and family roles are reported in Table III.

Analysis suggested that the total number of roles assigned by male and female authors at each grade level was approximately equivalent except at the grade 1-2 level. At this level, female authors included significantly more roles than male authors $(r=3.1, p<.01$ for female authors; $r=$ $-3.1, p<.01$ for male authors).

When frequencies of roles assigned by male and female authors were combined at each grade level, a developmental trend was apparent. Of the total 264 roles assigned, grade $1-2$ children assigned $38(14 \%)$ roles, grade 3-4 children assigned $89(34 \%)$ roles, and grade 5- 6 children assigned 137 $(52 \%)$ roles. There was a trend toward an increase in the assignment of roles with increasing age.

Further analysis of roles suggested that male and female authors differed in the number of roles which they assigned to each sex. An omnibus chi square suggested that sex of author, sex of character, and grade of author were significantly related, $\chi^{2}(7, N=180)=31.3, p<.001$. Since grade was independent of sex of author and sex of character, frequencies were collapsed across grade. This resulted in a significant relationship between author and character, $\chi^{2}(1, N=180)=18.9, p<.001$. The cell residuals suggested that male authors assigned significantly more roles to male characters $(r=4.3, p<.001)$ than female authors. Female authors assigned significantly more roles to female characters $(r=4.3, p<.001)$ than male authors. Although the assignment of roles to female characters was greater for female authors, female and male authors assigned more 
Table IV. Occupational Roles Assigned to Male and Female Characters by Each Grade Level ${ }^{a}$

\begin{tabular}{|c|c|c|c|}
\hline Authors & \multicolumn{2}{|c|}{ Male characters } & Female characters \\
\hline \multicolumn{4}{|c|}{ Grades 1-2 } \\
\hline Males & $\begin{array}{l}\text { doctor } \\
\text { spaceman } \\
\text { baseball player }\end{array}$ & $\begin{array}{l}\text { astronaut } \\
\text { clown }\end{array}$ & - \\
\hline Females & $\begin{array}{l}\text { storeman } \\
\text { king } \\
\text { ringmaster }\end{array}$ & $\begin{array}{l}\text { doctor } \\
\text { dentist } \\
\text { clown }\end{array}$ & $\begin{array}{l}\text { princess } \\
\text { cook }\end{array}$ \\
\hline \multicolumn{4}{|c|}{ Grades 3-4 } \\
\hline Males & $\begin{array}{l}\text { boss } \\
\text { prince } \\
\text { spaceman } \\
\text { mayor (4) } \\
\text { police man (3) } \\
\text { thief/robber (3) }\end{array}$ & $\begin{array}{l}\text { judge } \\
\text { king (2) } \\
\text { secretary } \\
\text { air force man } \\
\text { farmer } \\
\text { detective (7) }\end{array}$ & princess \\
\hline Females & $\begin{array}{l}\text { robber/thief (4) } \\
\text { policeman (3) } \\
\text { doctor }(2) \\
\text { manager (2) } \\
\text { botanist }\end{array}$ & $\begin{array}{l}\text { shoe store owner } \\
\text { horse rustler } \\
\text { surfer } \\
\text { king (2) }\end{array}$ & $\begin{array}{l}\text { teacher } \\
\text { hula dancer }(2)\end{array}$ \\
\hline \multicolumn{4}{|c|}{ Grades 5-6 } \\
\hline Males & $\begin{array}{l}\text { president (5) } \\
\text { detectives }(9) \\
\text { criminal } \\
\text { space center } \\
\text { employee } \\
\text { professor } \\
\text { paper boy } \\
\text { judge } \\
\text { bird watcher } \\
\text { sheriff } \\
\text { football player } \\
\text { murderer } \\
\text { hermit }\end{array}$ & $\begin{array}{l}\text { bobsled racer } \\
\text { mayor } \\
\text { soldier } \\
\text { banker } \\
\text { king (2) } \\
\text { policeman (2) } \\
\text { guard } \\
\text { captain } \\
\text { scientist } \\
\text { hunter } \\
\text { rescuer } \\
\text { fireman } \\
\text { coach } \\
\text { artist } \\
\text { lieutenant }\end{array}$ & $\begin{array}{l}\text { kidnapper } \\
\text { yeoman } \\
\text { sage }\end{array}$ \\
\hline Females & $\begin{array}{l}\text { employers (3) } \\
\text { mayor } \\
\text { astronaut } \\
\text { clown } \\
\text { ringmaster }(2)\end{array}$ & $\begin{array}{l}\text { tinsmith } \\
\text { salesperson (3) } \\
\text { rescuer } \\
\text { doctor } \\
\text { thief }\end{array}$ & $\begin{array}{l}\text { housekeeper } \\
\text { nurse } \\
\text { teacher } \\
\text { babysitter } \\
\text { salesperson (2) } \\
\text { illustrator }\end{array}$ \\
\hline
\end{tabular}

"When a role was assigned more than once, numbers in parentheses indicate the number of times. All other roles were assigned only once. 
roles to their male characters ( 98 , or $79 \%$ for male authors; 75 , or $54 \%$ for female authors) than to their female characters $(26$, or $21 \%$ for male authors; 65 , or $46 \%$ for female authors).

When family roles were eliminated and only occupational roles were considered, interesting results were found. Of the 127 occupational roles assigned to characters by male and female authors, $111(87 \%)$ were assigned to male characters and only $16(13 \%)$ were assigned to female characters. The occupational roles assigned to male and female characters are reported in Table IV, which suggests that both male and female writers assigned very few occupational roles to female characters. Male characters were assigned a wide variety of roles, many reflecting prestige, power, and authority.

\section{DISCUSSION}

The results of this study suggest similarities and differences between male and female writers at three grade levels. Male and female authors were similar in the total number of characters, attributes, and roles they generated in their stories. The frequencies of characters, attributes, and roles increased with increasing age.

Male and female writers differed in the distribution of male and female characters, their roles and attributes. At all grade levels, female writers included significantly more female characters than male writers. While $44 \%$ of the characters generated by female writers were female, only $14 \%$ of the characters generated by male authors were female. In addition, female writers assigned more attributes to female characters than male writers. This is particularly evident by the grade 5-6 level. By this age, female writers attributed $54 \%$ of their total attributes to female characters, while male writers attributed only $6 \%$ of their attributes to female characters. Finally, at all grade levels, female writers ascribed significantly more roles to female characters than did male writers.

An interesting developmental change was noted in the assignment of attributes among female writers. Below grades 5-6, female writers tended to ascribe more personal and ability traits to male rather than female characters. By grades 5-6, the reverse was indicated. As suggested by the developmental theory of Erikson (1950), the young adolescent is beginning to define and discover a sense of self-identity. Female writers at this age may have a stronger sense of self-awareness and an awareness of the characteristics of others like themselves. They may then assign more personal and ability traits to their female characters.

Even though female writers included more female characters and ascribed more attributes and roles to these characters, greater attention 
seemed to be given to male characters by both male and female writers. At all grade levels, male and female authors generated more male characters than female characters. With the exception of grade 5-6 females, male and female writers assigned more attributes and roles to male characters than female characters. Among male wirters, the lack of female characters with attributes and roles was marked. In addition, the scarcity of occupational roles assigned to female characters by all writers was very evident. Male characters were assigned a wide variety of roles, many of which represented power and prestige.

The predominance in children's writing of male characters assigned many attributes and roles is not surprising, given the models children are often presented. Several studies (Czaplinski, 1972; Hillman, 1974; Michigan Women's Commission, 1974; Weitzman, Eifler \& Ross, 1972) have suggested that school textbooks, picture books for preschool children, and literature for school-aged children tend to include more male characters than female characters. These male characters are often assigned more active, interesting and powerful roles than female characters.

There has been increased attention among educators and authors to present children with nonsexist models. Though not dramatic, some changes have been seen in the areas of children's literature and school curricula which present nonsexist learning opportunities (Collins, Ingoldsby, \& Dellman, 1984; Shapiro, Kramer, \& Hunerberg, 1981). Further efforts in this direction seem necessary if children's constructions of sex roles are to include both men and women as having important and varied roles in society.

\section{REFERENCES}

Collins, L., Ingoldsby, B., \& Dellman, M. Sex-role stereotyping in children's literature: A change from the past. Childhood Education, 1984, 60, 278-285.

Czaplinski, S. Sexism in award winning picture books. Pittsburgh: Know, Inc., 1972.

Erikson, E. H. Childhood and society. New York: Norton, 1950.

Everitt, B. S. The analysis of contingency tables. New York: Halstead Press, 1977.

Hillman, J. S. Analysis of male and female roles in two periods of children's literature. Journal of Educational Research, 1974, 68, 84-88.

Kohlberg, L. A cognitive-developmental analysis of children's sex-role concepts and attitudes. In E. E. Maccoby (Ed.), The development of sex differences. Stanford: Stanford University Press, 1966. Pp. 82-173.

Michigan Women's Commission. Sex discrimination in an elementary reading program. Lansing: Author, 1974.

Shapiro, J., Kramer, S., \& Hunerberg, C. Equal their chances. Englewood Cliffs, N.J.: PrenticeHall, 1981.

Weitzman, L. J., Eifler, E. H., \& Ross, C. Sex-role socialization in picture books for preschool children. American Journal of Sociology, 1981, 77, 1125-1150. 